\title{
Evaluation of professional awareness in physiotherapy and rehabilitation students of Afyon Kocatepe University
}

\author{
Emel Taşvuran Horata ${ }^{1 \mathrm{a}}$ and Suat Erel $^{2}$ \\ ${ }^{1}$ Afyon Health School, Department of Physiotherapy and Rehabilitation, Afyon Kocatepe University, \\ Afyonkarahisar 03100 , Turkey \\ ${ }^{2}$ School of Physical Therapy and Rehabilitation, Pamukkale University, Denizli 20160, Turkey
}

\begin{abstract}
In latest years, physiotherapists have been progressively interested in defining their professional identity. For this purpose, Physiotherapy and Rehabilitation Departments of universities in Turkey lecture courses about this profession. The students have the opportunity to improve their professional awareness in these courses. The aim of this research is to determine the professional awareness of the students of the Department of Physiotherapy and Rehabilitation at Afyon Kocatepe University. In the present study, "Professional Awareness Questionnaire" was applied to 227 students who is the first, second, third and fourth grade students at Afyon Kocatepe University. According to this study, the most correctly answered question was related to type of grade point for placement the department $(95.2 \%)$. Interns respond more questions correctly $(p<0.01)$. Prevalence of students who prefer the physiotherapy due to their interest is $40.5 \%$. There were no differences between the students who choose physiotherapy for their interest and the other reasons $(\mathrm{p}>0.05)$. In conclusion, the findings from this study show that professional awareness can be influenced by individual differences. However, the level of professional awareness and the interest in the profession of the student can be increased by professional courses.
\end{abstract}

Keywords: Professional awareness; physiotherapy; student

\section{Introduction}

Profession can be defined as a set of activities those rules are determined by society and based on knowledge, skills as a result of certain education. It provides individuals to earn their lives. Also it is most important factor that enables the individuals to establish their identity and a reciprocal relationship with the society and gain prestige. Therefore, the choice of profession is great importance for both individuals and society [1]. The suitable

\footnotetext{
${ }^{\text {a }}$ Corresponding author: ethorata@gmail.com
} 
choice of profession makes the individuals successful, happy and productive. Factors such as talent, interest, value and belief system, family culture and environment influence the individual's career choice [2].

A Profession is valuable because it serves humanity. Nowadays, rapid social change contributes to the formation of different professions, which leads to the reduction of the social status and economic possibilities of some professions. This creates problems for students in their professional preferences [3]. It is ideal to choose a profession based on the specific interests and skills of the individual. But most students consider the opportunity to find a job and the high-income levels when choosing a profession [1]. The most common reason for the preference of professions in the field of health sciences is also the opportunity to finding a job and the high-income level. Çiftçi and colleagues showed that only $78.9 \%$ of the students at the Department of Physiotherapy and Rehabilitation had detailed knowledge about the department before their preference. In addition, $24 \%$ of students in physiotherapy and rehabilitation department (if they had a chance to choose again) reported that they would prefer this department again [4].

Professional awareness requires knowledge of the competencies of the profession, occupational laws and regulations, duties and responsibilities, the individual's psychological and physical suitability to the profession, and professional sensitivity. In the society, it is vital to ensure professional awareness in the area of health that is necessary for individual happiness, economic efficiency and prosperity. With the increase in the quality of health services, it is possible to increase the level of economic efficiency and prosperity by improving the health condition in the groups with social problems. [5]

According to World Confederation for Physical Therapy (WCPT), physiotherapists provide services that develop, maintain and restore people's maximum movement and functional ability. They can help people at any stage of life, when movement and function are threatened by ageing, injury, diseases, disorders, conditions or environmental factors [6]. WCPT has arranged own ethical principles to make recommendation about this profession. These ethical principles include equality, obedience to the law, patient responsibility, professional health care and community health issues [7, 8]. Educational results for professions are obtained through the socialization of students to the values, attitudes and beliefs of their choosing profession and a commitment to a professional career $[9,10]$.

The first school of Physical Therapy and Rehabilitation is established at Hacettepe University in Turkey in 1961. Today, including private universities, there are a total of 52 departments of physiotherapy at the universities in Turkey and about 7900 physiotherapists graduated from these schools [8]. The Physiotherapy and Rehabilitation Department of Afyon Health School which was established at Afyon Kocatepe University in 2008 consists of 4-year undergraduate program. "Professional Orientation" course is included in the curriculum of the first-year students that has detailed information about the department and occupational subjects such as Physiotherapist Professional Law, World Physical Therapy Day, and Turkish Physiotherapy Association. The aim of this course is to provide the students to adaptation for school and improvement of their professional awareness.

Therefore, the main purpose of this study is to determine the professional awareness of students of the Department of Physiotherapy and Rehabilitation at Afyon Kocatepe University and investigate any differences between professional awareness of the students according to grades. And seconder purpose of this study is to search any differences between professional awareness of the students who prefer physiotherapy due to their interest and the others. For this purpose we hypotheses that:

(a) The students of in this study ratio of correct answer to questions which are about professional awareness are high

(b) Fourth-grade (intern) students answer more correctly to questions about professional awareness. 
(c) The students who prefer physiotherapy due to their interest answer more correctly to questions about professional awareness.

\section{Method}

The present study is a descriptive study that evaluates the professional awareness of the students of the Department of Physiotherapy and Rehabilitation at Afyon Kocatepe University. The Afyon Kocatepe University Health Sciences Scientific Research and Publication Ethics Committee gave approval for the present study and informed consent was obtained from each participant at the beginning of the study.

\subsection{Participants}

The first, second, third and fourth-grade students of the Department of Physiotherapy and Rehabilitation were included the study.

\subsection{Procedure}

In the previous study, Razak Özdinçler and colleagues [12] applied the professional awareness questionnaire to the students of Department of Physiotherapy and Rehabilitation of the Faculty of Health Sciences at Istanbul University. In our study, we arranged the previous questions according to our department. The questionnaire consists of 15 questions about Physiotherapist Professional Law, World Physical Therapy Day, Turkish Physiotherapy Association, the Department of Physiotherapy and Rehabilitation and postgraduate education. Also, we added a question about the reasons for choosing this department.

Approximately 10 minutes were given to students to complete the questionnaire. In addition, the questionnaire was applied in the classrooms and supervisor-guided.

For the statistical analysis of the study, 22.0 version of the Windows-based SPSS program was used. We summarized the descriptive analysis of correct answers. Also we analysed the difference in correct answers among the grades by using ANOVA and between the students who prefer physiotherapy due to their interest and the others by using t-test. Values of $\mathrm{p}$ less than 0.05 were considered statistically significant.

\section{Findings}

In the present study, "Professional Awareness Questionnaire" was applied to 227 students who is the first, second, third and fourth-grade students at Afyon Kocatepe University. We recruited $64(28.2 \%)$ students of first grade, $56(24.7 \%)$ of second grade, $70(30.8 \%)$ of third grade, $37(16.3 \%)$ of fourth-grade students participated. The average age of participants was $20.58 \pm 1.53$ years and $152(67.0 \%)$ participants were women and 75 $(33.0 \%)$ were men.

According to this study, more correctly answered questions were; $95.2 \%$ of the participants respond correctly the question about type of grade point for placement the department, $84.6 \%$ the conditions required for master and $82.4 \%$ World Physical Therapy Day, respectively. Also less correctly answered questions were; $30.4 \%$ of the participants respond correctly the question about Physiotherapist Professional Law formation and $38.8 \%$ the minor at the department (Table 1). Post hoc comparisons using Tukey's honest significant difference test indicated that interns answer more questions correctly between groups $(\mathrm{p}<0.01)$. There were no differences between first-grade and second-grade students, first-grade and third-grade students and second-grade and third-grade students $(p>0.05)$. 
Table 1. Level of the participant's professional awareness

\begin{tabular}{|c|c|c|c|c|}
\hline \multirow{2}{*}{ Questions } & \multicolumn{2}{|c|}{ Correct answers } & \multicolumn{2}{|c|}{ Wrong answers } \\
\hline & $\mathrm{n}$ & $\%$ & $\mathrm{n}$ & $\%$ \\
\hline When was the Physiotherapist Professional Law made? & 69 & 30.4 & 158 & 69.4 \\
\hline When is the World Physical Therapy Day celebrated? & 187 & 82.4 & 40 & 17.6 \\
\hline $\begin{array}{l}\text { Which is Turkish Physiotherapy Association a member of } \\
\text { international organization? }\end{array}$ & 127 & 55.9 & 100 & 44.1 \\
\hline $\begin{array}{l}\text { Which year was the first physiotherapy department at the } \\
\text { universities in Turkey established? }\end{array}$ & 133 & 58.6 & 94 & 41.4 \\
\hline $\begin{array}{l}\text { How many credits are required to graduate from } \\
\text { Department of Physiotherapy and Rehabilitation at Afyon } \\
\text { Kocatepe University? }\end{array}$ & 141 & 62.1 & 86 & 37.9 \\
\hline $\begin{array}{l}\text { How many credits does students of Department of } \\
\text { Physiotherapy and Rehabilitation at Afyon Kocatepe } \\
\text { University have each semester? }\end{array}$ & 120 & 52.9 & 107 & 47.1 \\
\hline $\begin{array}{l}\text { Which is type of grade point for getting into Department of } \\
\text { Physiotherapy and Rehabilitation at Afyon Kocatepe } \\
\text { University? }\end{array}$ & 216 & 95.2 & 11 & 4.8 \\
\hline $\begin{array}{l}\text { Which branch do you have an opportunity to do minor at } \\
\text { Department of Physiotherapy and Rehabilitation at Afyon } \\
\text { Kocatepe University? }\end{array}$ & 88 & 38.8 & 139 & 61.2 \\
\hline $\begin{array}{l}\text { What are the conditions for master in Department of } \\
\text { Physiotherapy and Rehabilitation at the universities in } \\
\text { Turkey? }\end{array}$ & 192 & 84.6 & 35 & 15.4 \\
\hline $\begin{array}{l}\text { According to the latest adopted resolution by the Ministry } \\
\text { of Health, which physicians do orient the physiotherapists } \\
\text { for patients' physiotherapy program? }\end{array}$ & 113 & 49.8 & 114 & 50.2 \\
\hline $\begin{array}{l}\text { Who is the president of the Turkish Physiotherapist } \\
\text { Association? }\end{array}$ & 109 & 48.0 & 118 & 52.0 \\
\hline
\end{tabular}

Reasons for choosing this profession were; $40.5 \%$ of students chose because of their interests, $17.6 \%$ job opportunities, $17.2 \%$ friend or teacher referral, $9.7 \%$ family pressure and $13.2 \%$ others. There were no differences between the students who prefer physiotherapy due to their interest and the others in terms of correct answers $(p>0.05)$.

\section{Discussion and Conclusion}

In the present study, we searched professional awareness of the students at the Department of Physiotherapy and Rehabilitation at Afyon Kocatepe University. For this purpose we conducted Professional Awareness Questionnaire to 227 students who is the first, second, third and fourth-grade students at Afyon Kocatepe University.

According to results of our study, we showed that participants answer more correctly questions about the Department of Physiotherapy and Rehabilitation except the question about minor. The question about type of grade point for placement the department is the most correctly answered (95.2\%). Also the question about Physiotherapist Professional Law formation is the least correctly answered. Razak Özdinçler and collages [12] applied Professional Awareness Questionnaire to 201 students of Department of Physiotherapy and Rehabilitation of the Faculty of Health Sciences at Istanbul University. In the previous study participants' ratio of correct answer to questions which were about Physiotherapist Professional Law was higher (73.63\%). We are surprised that different results between two universities. These results are thought this question might be relevant for individual concern. The correct answer rates of the questions related to the department and the master 
are similar. In this study we adapted the questions about department and master for participants; this was effective in obtaining similar results.

We showed that there were significant differences between interns and first, second and third-grade students. Interns answered questions more correctly than other grades. In fact we expected the increasing of awareness in progressive grades, no significant differences between grades. The previous study supports our findings; they claimed that there were no differences between grades but also they found that fourth-grade students had a higher percentage of responding to questions related to master conditions [12]. Similarly, Kunduracilar and collages conducted with the first-grade students of questionnaire about their professional awareness in the physiotherapy and rehabilitation, [5]. Based on the findings of their studies on the evaluation stated that level of "awareness of qualifications in physiotherapy" and "professional sensitivity" were high, even though did not even take basic professional courses. However they did not include first, second and fourth-grade students in their research [5]. At the Department of Physiotherapy and Rehabilitation of Afyon Kocatepe University, interns practise in the hospital differently than other grades and thus spend more time with the patients and the physiotherapists working there. This may have increased their level of professional awareness. In addition, interns may be anxious to find a job after graduation and they may want to study for master degree. Therefore, they may have more knowledge about professional law, department, graduate and Turkish Physiotherapy Association related questions than others.

Based on results of the present research; $40.5 \%$ of the participants preferred this department due to their interest, $17.6 \%$ job opportunities, $17.2 \%$ friend or teacher referral, $9.7 \%$ family pressure and $13.2 \%$ others. In the previous research, Kunduracilar and collages [5] obtained similar results. They found that the percentage of participants who preferred this department due to their interest and job opportunities was higher than the participants who preferred it for other reasons [5]. Öhman and collages [13] asked to the Canadian students who study in physiotherapy, the reasons for the career choice and professional preferences. According to their study "Six factors influenced the students' choice of career." Job opportunity and the potential to earn a good salary were the most frequently chosen reasons $(25.5 \%)$. Other reasons are a positive exposure to the profession, the interesting aspects of the profession, a desire to be able to help other people and interest in sports and athletic injuries [13]. Gotlib and collages [14] investigated that the attitudes of European physiotherapy students towards their chosen career. An interest in physiotherapy was the main reason why students decided to study physiotherapy, with more than $79 \%$ of students indicating that this was the most important factor in their decision, according to their studies [14]. Different living conditions in communities also change the status within the profession $[3,4]$. We believe that this affects the reasons for the preferences of the profession in the future.

In our study, there were no differences between the students who prefer physiotherapy due to their interest and the others in terms of correct answers $(p>0.05)$. We expected that the participants who prefer due to their interest have more correctly answered questions. Kunduracilar and collages [5] claimed that the students who prefer physiotherapy due to their interest have higher levels of awareness for competences in physiotherapy and professional awareness. However, according to Razak Özdinçler and collages "Professional success and satisfaction are related to the individual's awareness of individual characteristics and capabilities." [12]. Also we believed that because each of the students has taken "Professional Orientation" course increases the level of professional awareness of the non-interested students.

In conclusion, the findings from this study show that professional awareness can be influenced by individual differences. However, the level of professional awareness and the interest in the profession of the student can be increased by professional courses at the beginning of undergraduate education. Therefore professional courses should consist of 
contemporary knowledge about professional law, post graduate education and department. Also these courses should be guidance to student on plans of career in the future.

\section{References}

1. T. Sarıkaya, L. Khorshid. Üniversite öğrencilerinin meslek seçimini etkileyen etmenlerin incelenmesi: Üniversite öğrencilerinin meslek seçimi. Türk Eğitim Bilimleri Dergisi, 7, 2 (2009)

2. Y. Kuzgun, Meslek Danışmanlığ (Doğuş Matbaacılık, Ankara, 2000)

3. A. Karakuş, N. Karadağ, F. Bilgili, Ç. Işıkay, G. Çadır, D. Çeker. Lise son sınıf kız öğrencilerinin hemşirelik mesleğine bakış açıları ile mesleği tercih etme durumları. Hemşirelik Forumu Dergisi, 5, 1 (2005).

4. G. E. Çiftçi, S. F. Bülbül, N. Bayar Muluk, G. Çamur Duyan, A. Yılmaz. Factors in selecting a university and career among students studying in the Faculty of Health Sciences (Kirikkale University). J Kartal TR, 22, 3 (2011).

5. Z. Kunduracılar, E. Akbaş, Ç. Büyükuysal, D. Biçki, E. U. Erdam. Assessment of job awareness in Department of Physical Therapy and Rehabilitation students. J High Educ Science 2, 3 (2012).

6. World Confederation for Physical Therapy (WCPT). Policy statement: Description of physical therapy. (WCPT, London, UK, 2017). http://www.wcpt.org/policy/psdescriptionPT

7. World Confederation for Physical Therapy (WCPT). Ethical principles. (WCPT, London, UK, 2017). www.wcpt.org/ethical-principles

8. World Confederation for Physical Therapy (WCPT). Policy statement: Ethical responsibilities of physical therapists and WCPT members. (WCPT, London, UK, 2017). http://www.wcpt.org/policy/ps-ethical-responsibilities

9. I. Lindquiist, M. Engardt, L. Garnham, F. Poland, B. Richardson. Physiotherapy students' professional identity on edge of working life. Medical Teacher, 28, 3 (2006).

10. H.M. Vollmer, D.L. Mills. Professionalisation (Prentice Hall, Englewood Cliffs, NJ, 1966).

11. F. Can. Professional development history of physical therapy and rehabilitation. İKÇÜSBFD, 1, 3 (2016).

12. A. Razak Özdinçler, E. Tarakci, Y. Aslan. Investigation of professional awareness of students in Physiotherapy and Rehabilitation Division. HSP, 2, 2 (2015).

13. A. Öhman, P. Solomon, E. Finch. Career choice and professional preferences in a group of Canadian Physiotherapy Students. Advances in Physiotherapy, 4, $16-22$ (2002).

14. J. Gotlib, D. Białoszewski, J. Opavsky, R. Garrod, N. E. Fuertes, L. P. Gallardo, B. P. Lourido, S. Monterde, C. S. Serrano, M. Sacco, I. Kunicka. Attitudes of European physiotherapy students towards their chosen career in the context of different educational systems and legal regulations pertaining to the practice of physiotherapy: implications for university curricula. Physiotherapy 98, 76-85 (2012). 